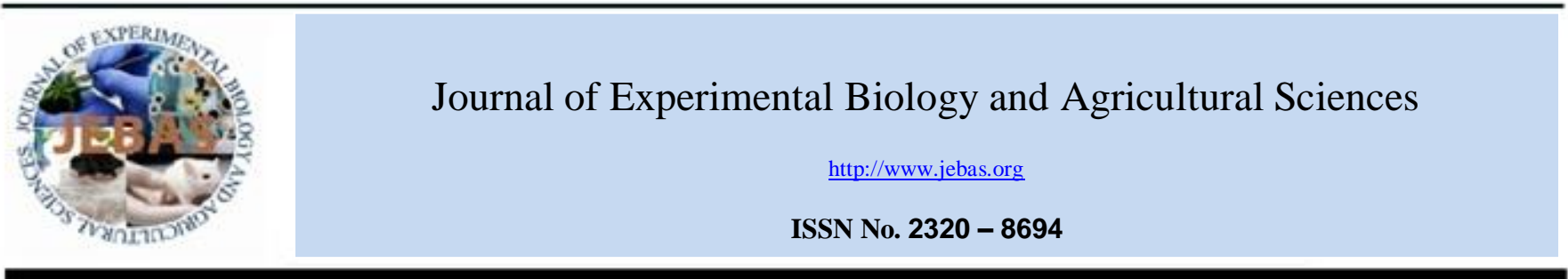

\title{
ANTIDIABETIC POTENTIAL OF Costus igneus LEAF IN STREPTOZOTOCIN INDUCED DIABETIC WISTAR ALBINO RATS
}

\author{
Waseem Iqbal Khanday ${ }^{1}$, Nazir Ahmad Wani ${ }^{2}$, Balaji Paulraj ${ }^{1, *}$
}

${ }^{1} \mathrm{PG}$ and Research Centre in Biotechnology, MGR College, Hosur - 635130, Tamilnadu, India

${ }^{2}$ Department of Microbiology and Biotechnology Bangalore University Bangalore 560056

Received - December 04, 2018; Revision - January 06, 2019; Accepted - January 17, 2019

Available Online - February 5, 2019

DOI: http://dx.doi.org/10.18006/2019.7(1).65.73

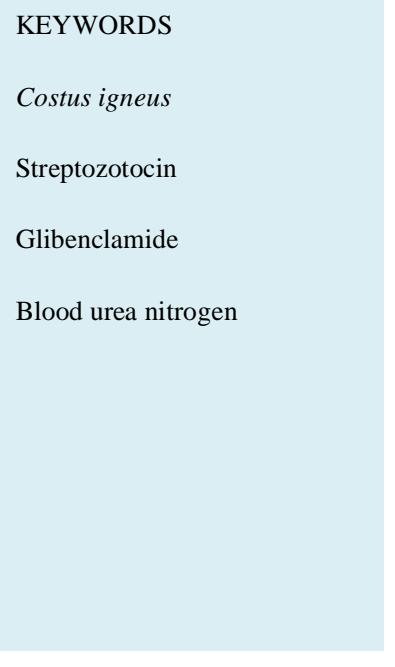

\begin{abstract}
Traditional herbal medicinal plants leaves essentially reduced the fasting and postprandial blood sugar levels and bringing them down towards normal. The present study was aimed to evaluate acute toxicity, in vivo anti-diabetic effect of $C$. igneus on streptozotocin induced diabetic wistar albino rats by estimating total cholesterol, triglycerides, high density lipoprotein, low density lipoprotein, very low density lipoprotein cholesterol, serum creatinine and blood urea nitrogen. The result of acute toxicity study revealed that various tested extracts did not show any mortality at all tested concentration. Further, hexane extract of $C$. igneus leaves at $200 \mathrm{mg}$ showed significant $(\mathrm{P}<0.001)$ reduction in blood sugar level ( $114.8 \pm 7.08)$ while in case of $400 \mathrm{mg}$ hexane leaf extract this reduction in sugar level $(91.6 \pm$ 6.12) was started from day $7^{\text {th }}$ to $28^{\text {th }}$ day. Further, the same treatment also showed highly significant $(\mathrm{P}<0.001)$ reduction in blood urea nitrogen $(30.52 \pm 1.42)$ and it was equipotent as that of Glibenclamide. Similarly significant reduction in serum creatinine level was observed at $400 \mathrm{mg} / \mathrm{kg}$ in all the three leaf extracts of $C$. igneus and was similar to the effect produced by that of Glibenclamide. The present study explored the significant anti-diabetic potential of $C$. igneus and from the results of the study it can be concluded that $C$. igneus can be used as safe and cost-effective herbal drug for the treatment of diabetes.
\end{abstract}

* Corresponding author

E-mail: balaji_paulraj@yahoo.com (Dr. P. Balaji)

Peer review under responsibility of Journal of Experimental Biology and Agricultural Sciences.

Production and Hosting by Horizon Publisher India [HPI] (http://www.horizonpublisherindia.in/).

All rights reserved.
All the article published by Journal of Experimental Biology and Agricultural Sciences is licensed under a Creative Commons Attribution-NonCommercial 4.0 International License Based on a work at www.jebas.org.

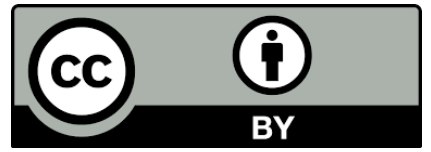




\section{Introduction}

Diabetes is a metabolic disorder of endocrine system that participate disturbance in glucose, lipid and protein homoeostasis (Van et al., 2006). Diabetes is generally characterized by hyperglycemia, glucosuria, polyuria and loss of body weight (Tende et al., 2011). Various allopathic medicines are available for the treatment of diabetes but these have various side effects. Traditional herbal medicinal plants have been used widely to effectively treat diabetes (Mukherjee et al., 2006), these herbal products are safer than synthetic formulation (Abou \& Ghanema, 2013). Plants which have hypoglycemic action act on blood glucose through several mechanisms. Some of them may inhibit endogenous glucose production (Eddouks et al., 2003) or interfere the gastrointestinal glucose absorption (Musabayane et al., 2006), some may produce insulin like substance (Collier et al., 1987; Gray\&Flatt,1999) some may inhibit insulinase activity and some may enhance secretion of insulin from $\beta$ cells of the pancreas (Khan et al., 1990; Trivedi et al., 2004; Yadav et al.,2008). While some plants may proliferate $\beta$ cells in pancreas by activating regeneration of these cell (Shanmugasundaram et al., 1990). In diabetes, free radicals are adversely formed through glucose oxidation, non-enzymatic glycation of proteins, and the subsequent oxidative degradation of glycated proteins (Maritim et al., 2003; Mehta et al., 2006). Cancers, diabetes, heart and brain related disease are mainly caused by production of free radicals which alter the structural and functional cell components in human beings (Mclarty, 1997; Yang et al., 2001; Young \&Wood, 2001; Sun et al., 2002;Bimal et al., 2011). Large number of plants reputed to possess anti-diabetic properties (Saraswat et al., 2010; Ugwuja et al., 2010; Jafri et al., 2011). Among these very few have received equitable scientific and medical scrutiny in terms of their anti-glycation activities. The currently available anti-diabetic drugs may have some limitations and side effects therefore the growing trend for diabetes treatment was directed to the use of natural agents, such as medicinal herbs (Awanish et al., 2011). Therefore present study was aimed to evaluate acute toxicity, invivo anti-diabetic effect of $C$. igneus on streptozotocin induced diabetic wistar albino rats and determination of various biochemical parameters.

\section{Materials and methods}

\subsection{Collection and identification of plant material}

The leaves of $C$. igneus were collected from the outskirts of Hosur, Krishnagiri district of Tamil Nadu and identified on the behalf of taxonomy key developed by Dr. M. Kumar, Assistant Professor, Department of Plant Biology and Biotechnology at Madras Christian College, Chennai Tamil Nadu India. The collected leaf materials were cleaned shade dried and powdered for further extraction.

\subsection{Preparation of extracts}

The air dried leaf powdered of C. igneus were extracted in Soxhlet extractor for 8-10 hrs, successively with acetone, hexane and hot water and the air dried residues were further extracted with hot water by the method of maceration for $24 \mathrm{hrs}$ and the material was dried in hot air oven at $40^{\circ} \mathrm{C}$. The evaporated extracts thus obtained were dissolved in the respective solvents at the concentration of $1 \mathrm{mg} / \mathrm{mL}$ and used for further in vivo studies.

\subsection{Animals and Management}

The experiments were carried out using Wistar albino rats (150$200 \mathrm{~g}$ ) procured from the Animal house, Nandha college of Pharmacy, Erode, Tamilnadu, India. On arrival the animals were placed at random and allocated to treatment groups in polypropylene cages with paddy husk as bedding. Animals were housed at a temperature of $24 \pm 2^{\circ} \mathrm{C}$ and relative humidity of $30-$ $70 \%$. A 12:12 light:dark cycle was followed. All animals were allowed to free access to water and fed with standard commercial rat chaw pallets (M/s. Hindustan Lever Ltd, Mumbai). All the experimental procedures and protocols used in this study were reviewed by the Institutional Animal Ethics Committee (Regd. no: 688/PO/Re/S/02/CPCSEA) and were in accordance with the guidelines of the CPCSEA.

\subsection{Acute toxicity study}

Acute toxicity studies were performed according to OECD-423 (Organization of Economic and Cooperation Development) guidelines. Male Swiss mice were selected by random sampling technique for this study. The animals $(\mathrm{n}=5)$ were fasted for $4 \mathrm{hrs}$ with free access to water. The different leaf extracts of $C$. igneus was administered orally at a dose of $5 \mathrm{mg} / \mathrm{kg}$ initially and mortality if any was observed for 3 days. If any mortality was observed in two out of three animals, then the dose administered was considered as toxic dose. However, if the mortality was observed in only one animal out of three animals then the same dose was repeated again to confirm the toxic effect. If no mortality was observed, then higher $(50,300,2000 \mathrm{mg} / \mathrm{kg})$ doses of the different leaf extracts of $C$. igneus were employed for further toxicity studies. The following general behaviour sedative, hypnotics, convulsion, ptosis, analgesia, stupar reaction, motor activity, muscle relaxant, pilo erection, change in skin colour, lacrimal secretion, stool consistency was also observed during the acute toxicity study Ecobichon,(1997).

\subsection{Experimental induction of diabetes}

For inducing the diabetes, all the experimental group animals were kept fasting for overnight. Diabetes was induced by intraperitoneal injection of streptozotocin (STZ) dissolved in $0.1 \mathrm{M}$ cold sodium citrate buffer, $\mathrm{pH} 4.5$, at a dose of $55 \mathrm{mg} / \mathrm{kg}$ (Aslam 
et al., 2007). Group one and two served as untreated healthy, untreated streptozotocin diabetic control and received distilled water. To overcome the drug induced hypoglycaemia the animals were allowed to drink 5\% glucose solution overnight. A week later the blood glucose level were checked, the rats with blood glucose range of above $200 \mathrm{mg} / \mathrm{dl}$ were considered as diabetic rats and used for the experiment.

\subsection{Experimental design}

For evaluating the hypoglycemic effect of various extracts of $C$. igneus all the animals were randomly divided in to 9 groups with 5 animals in Each group.

\begin{tabular}{|ll|}
\hline Group I & $\begin{array}{l}\text { Normal control (Non - diabetic) received } \\
\text { distilled water } 1 \mathrm{ml} / \mathrm{kg}\end{array}$ \\
\hline Group II & $\begin{array}{l}\text { Diabetic (streptozotocin induced) rats received } \\
\text { distilled water } 1 \mathrm{ml} / \mathrm{kg}\end{array}$ \\
\hline Group III & $\begin{array}{l}\text { Diabetic rats received Standard drug } \\
\text { Glibenclamide } 5 \mathrm{mg} / \mathrm{kg}\end{array}$ \\
\hline Group IV & $\begin{array}{l}\text { Diabetic rats received } 200 \mathrm{mg} / \mathrm{kg} \text { hot water } \\
\text { extract of } C \text {. igneus leaf }\end{array}$ \\
\hline Group V & $\begin{array}{l}\text { Diabetic rats received } 400 \mathrm{mg} / \mathrm{kg} \text { hot water } \\
\text { extract of } C \text {. igneus leaf }\end{array}$ \\
\hline Group VI & $\begin{array}{l}\text { Diabetic rats received } 200 \mathrm{mg} / \mathrm{kg} \text { of acetone } \\
\text { extract of C. igneus leaf }\end{array}$ \\
\hline Group VII & $\begin{array}{l}\text { Diabetic rats received } 400 \mathrm{mg} / \mathrm{kg} \text { of acetone } \\
\text { extract of } C \text {. igneus leaf }\end{array}$ \\
\hline Group VIII & $\begin{array}{l}\text { Diabetic rats received } 200 \mathrm{mg} / \mathrm{kg} \text { of hexane } \\
\text { extract of } C \text {. igneus leaf }\end{array}$ \\
\hline Group IX & $\begin{array}{l}\text { Diabetic rats received } 400 \mathrm{mg} / \mathrm{kg} \text { of hexane } \\
\text { extract of C. igneus leaf }\end{array}$ \\
\hline
\end{tabular}

All the above mentioned experiments were carried out for a period of 28 days. Blood glucose levels were determined on initial $(0$ day), $4^{\text {th }}, 7^{\text {th }}, 14^{\text {th }}$ and $28^{\text {th }}$ day. On $29^{\text {th }}$ day the animals under pento-barbitone sodium anesthesia, blood was collected through sinus or retro-orbital puncture and serum was separated for biochemical estimations.

\subsection{Determination of serum lipid profile}

The blood was collected through sinus or retro-orbital puncture from the animals on the termination day, serum was separated and subjected for analysis of total cholesterol, triglycerides, high density lipoprotein cholesterol, low density lipoprotein, very low density lipoprotein cholesterol, creatinine and blood urea nitrogen.

\subsubsection{Total cholesterol}

The analysis of total cholesterol in serum was determined by a colorimetric method described by Roeschlau et al. (1974). This assay principally based on enzymatic hydrolysis and oxidation of cholesterol and the indicator compound, quinoneimine is formed from hydrogen peroxide and 4-aminoantipyrine in the presence of phenol and peroxidase. Composition of reagents involves the mixture of following, 4-aminoantipyrine $(0.03 \mathrm{mmol} / \mathrm{l})$, phenol (6 $\mathrm{mmol} / \mathrm{l})$, peroxidase $(\geq 0.5 \mathrm{U} / \mathrm{ml})$, cholesterol esterase $(>0.15$ $\mathrm{U} / \mathrm{ml})$, cholesterol oxidase $(>0.1 \mathrm{U} / \mathrm{ml})$ and pipes buffer $(80$ $\mathrm{mmol} / \mathrm{L} \mathrm{pH} \mathrm{6.8).} \mathrm{The} \mathrm{serum} \mathrm{sample}(10 \mu \mathrm{l})$ was mixed with $1 \mathrm{ml}$ of reagent, incubated at $37^{\circ} \mathrm{C}$ for $5 \mathrm{~min}$, and absorbance measured at $500 \mathrm{~nm}$ against the reagent blank.

\subsubsection{Triglycerols}

The determination of triglycerides (TG) was carried out by colorimetric method given by Tietz, (1990). Principle of the assay involves enzymatic hydrolysis of TG with lipases and the indicator is a quinoneimine formed from hydrogenperoxide, 4-aminophenazone and 4-chlorophenol under the catalytic activity of peroxidase The enzyme reagent consisted of 4-aminophenazone $(0.5 \mathrm{mmol} / \mathrm{l})$, ATP $(1.0 \mathrm{~m} . \mathrm{mol} / \mathrm{l})$, lipases $(\geq 150 \mathrm{U} / \mathrm{ml})$, glycerol-kinase $(\geq 0.4 \mathrm{U} / \mathrm{ml})$, glycerol-3phosphate oxidase $(\geq 1.5 \mathrm{U} / \mathrm{ml})$, peroxidase $(\geq 0.5 \mathrm{u} / \mathrm{ml})$. The serum sample $(10 \mu \mathrm{l})$ was mixed with $1000 \mu \mathrm{l}$ of enzyme reagent, incubated at $37^{\circ} \mathrm{C}$ for $5 \mathrm{~min}$ and absorbance measured at $500 \mathrm{~nm}$ against the reagent blank.

\subsubsection{HDL Cholesterol}

Serum HDL cholesterol was determined using a colorimetric method described by Lopes et al. (1977). Principally the assay is based on quantitatively precipitation of low density lipoproteins (LDL and VLDL) and chylomicron fraction by the addition of phophotungstic acid in the presence of magnesium ions. The cholesterol concentration in the HDL fraction after centrifugation remains in the supernatant is determined. The precipitation reagents consisted of phosphotungstic acid $(0.55 \mathrm{mmol} / \mathrm{l})$ and magnesium chloride $(25 \mathrm{mmol} / \mathrm{l})$. The serum sample $(200 \mu \mathrm{l})$ was mixed with $500 \mu \mathrm{l}$ of precipitation reagent and centrifuged at 4000 $\mathrm{rpm}$ for $10 \mathrm{~min}$. The supernatant $(100 \mu \mathrm{l})$ was incubated at $37^{\circ} \mathrm{C}$ for $5 \mathrm{~min}$ and absorbance measured at $500 \mathrm{~nm}$ against the reagent blank. The cholesterol standard was $200 \mathrm{mg} / \mathrm{dL}(5.17 \mathrm{mmol} / \mathrm{l})$. The concentration of cholesterol in the supernatant was calculated by following formula

\section{HDL Cholesterol $=\Delta \mathrm{A}$ sample $/ \Delta \mathrm{A}$ standard $\mathrm{x}$ concentration of standard}

\subsubsection{LDL and VLDL Cholesterol}

The calculation of low density lipoprotein (LDL) and Very low density lipoprotein (VLDL) was done according to Friedwald formula (Friedewald et al., 1972). 
$\mathrm{LDL}=\mathrm{TC}-\mathrm{HDL}-\mathrm{VLDL}$,

VLDL cholesterol $=$ Triglycerides $/ 5$

\subsubsection{Estimation of Blood Urea}

Estimation of blood urea nitrogen was performed according to method given by Natelson et al. (1951). Three test-tubes were taken and labelled as B, T and S. In test tube B $0.02 \mathrm{ml}$ of water was pipetted, in test tube $\mathrm{T} 0.02 \mathrm{ml}$ of blood was taken and in test tube $\mathrm{S} 0.02 \mathrm{ml}$ of standard solution of urea $(40 \mathrm{mg}$ urea in $100 \mathrm{ml}$ of water) was taken. To all three testtube $0.1 \mathrm{ml}$ of diacetylmonoxime solution and $5 \mathrm{ml}$ of acid regent (Thiosemicarbazide) was added. The reaction mixture in these test tubes was mixed and kept in a boiling water bath for 15 minutes. After cooling, the absorbance was read at $540 \mathrm{~nm}$ and concentration of urea in $\mathrm{mg} / \mathrm{dl}$ was calculated.

\subsubsection{Estimation of Serum Creatinine}

The estimation of serum creatinine was performed according to the method described by Slot, (1965). Three test-tubes were taken and labelled as B, T and S. $2 \mathrm{ml}$ of water was taken in test tube B, $2 \mathrm{ml}$ of serum and $4 \mathrm{ml}$ of water was taken in test tube $\mathrm{T}$ and in test tube $\mathrm{S}, 3 \mathrm{ml}$ of water and $1 \mathrm{ml}$ of creatinine was taken. $2 \mathrm{ml}$ of ammonium sulphate and $2 \mathrm{ml}$ of sodium tungstate was added in all the three test-tubes and centrifuged. $3 \mathrm{ml}$ of supernatant was removed from each test tube and to the supernatant $1 \mathrm{ml}$ of picric acid and distilled water was added. Absorbance was read at 520 $\mathrm{nm}$ and concentration of serum creatinine in $\mathrm{mg} / \mathrm{dl}$ was calculated.

\subsection{Statistical Analysis}

The values of results were expressed as mean \pm SEM. The statistical analysis of data was carried out by one way analysis of variance (ANOVA) followed by Dunnet's ' $\mathrm{t}$ ' - test. $P$ values $<0.05$ were considered significant.

\section{Results}

\subsection{Oral acute toxicity study of various leaf extracts of $C$. igneus}

The results of acute toxicity study of hot water, acetone and hexane extracts of C. igneus leaf were shown in Table 1. All tested leaf extracts of $C$. igneus has not shown any mortality even after 72 hours at $2000 \mathrm{mg} / \mathrm{kg}$. The acetone and hexane extracts of $C$. igneus leaves showed mile sedation and hexane extract showed muscle relaxant and CNS depressant activity at $2000 \mathrm{mg} / \mathrm{kg}$. While hot water extract of C. igneus leaves didn't alter any of the general behaviour. There was no lethality or toxic reported during and after the study period with all the three different leaf extract of C. igneus.

\subsection{Hypoglycemic effect of $C$. igneus leaf extract}

The effect of different leaf extracts of C. igneus was studied for its hypoglycemic effect against Streptozotocin induced diabetic rats and the results are shown in Table 2. Glibenclamide was used as reference control and it significantly reduced the blood sugar levels from $4^{\text {th }}$ day on wards and on $28^{\text {th }}$ day the blood sugar was

Table 1 Oral acute toxicity study of different leaf extracts of C. igneus $(2000 \mathrm{mg} / \mathrm{kg})$ in mice

\begin{tabular}{|ccccc|}
\hline S. No. & General Behaviour & Hot Water Extracts & Acetone Extracts & Hexane Extracts \\
\hline 1 & Sedation & - & + & - \\
\hline 2 & Hypnosis & - & - & - \\
\hline 3 & Convulsion & - & - & - \\
\hline 4 & Ptosis & - & - & - \\
\hline 5 & Analgesia & - & - & - \\
\hline 6 & Stupar Reaction & - & - \\
\hline 7 & Motor activity & - & - \\
\hline 8 & Muscle Relaxant & - & - & - \\
\hline 9 & CNS Stimulant & - & - & + \\
\hline 10 & CNS Depressant & - & - \\
\hline 11 & Pilo Erection & - & - \\
\hline 12 & Skin Colour & - & - & - \\
\hline 13 & Lacrimation & - & - & - \\
\hline 14 & Stool Consistancy & - & - \\
\hline
\end{tabular}

Journal of Experimental Biology and Agricultural Sciences http://www.jebas.org 
Table 2 Effect of different extracts of $C$. ignus leaf on blood sugar level in Streptozotocin induced wistar albino rats

\begin{tabular}{|c|c|c|c|c|c|c|}
\hline \multirow{2}{*}{ Group } & \multicolumn{6}{|c|}{ Blood Sugar Level (mg/dl) } \\
\hline & Initial & After STZ & $4^{\text {th }}$ day & $7^{\text {th }}$ day & $14^{\text {th }}$ day & $28^{\text {th }}$ day \\
\hline Normal control & $98 \pm 4.66$ & $98.2 \pm 3.12$ & $101.2 \pm 7.15$ & $91.0 \pm 6.37$ & $98.2 \pm 3.94$ & $94.6 \pm 3.56$ \\
\hline Diabetic control & $100.6 \pm 8.12$ & $213.0 \pm 9.62$ & $220.2 \pm 8.15$ & $215.2 \pm 9.06$ & $215.4 \pm 8.92$ & $222 \pm 9.12$ \\
\hline Standard Glibenclamide $(5 \mathrm{mg} / \mathrm{kg}$ ) & $88.0 \pm 3.41$ & $217.6 \pm 3.72$ & $175.8 \pm 3.69^{*}$ & $151.6 \pm 4.03 * *$ & $129.2 \pm 2.92 * * *$ & $119.8 \pm 3.16^{* * *}$ \\
\hline Hot water extract $200 \mathrm{mg} / \mathrm{kg}$ & $100.6 \pm 9.96$ & $212.2 \pm 8.12$ & $196.2 \pm 8.06$ & $173.6 \pm 7.84 * *$ & $169.2 \pm 7.92 * *$ & $142.8 \pm 8.02 * *$ \\
\hline Hot water extract $400 \mathrm{mg} / \mathrm{kg}$ & $97.2 \pm 6.12$ & $213.8 \pm 8.31$ & $184.2 \pm 7.39 *$ & $164.8 \pm 7.82 * *$ & $141.8 \pm 6.94 * *$ & $120.0 \pm 7.09 * * *$ \\
\hline Acetone extract $200 \mathrm{mg} / \mathrm{kg}$ & $98.0 \pm 6.51$ & $211.8 \pm 7.36$ & $185.6 \pm 7.81^{*}$ & $178.0 \pm 8.01 *$ & $143.8 \pm 6.94 * *$ & $117.0 \pm 7.01 * * *$ \\
\hline Acetone extract $400 \mathrm{mg} / \mathrm{kg}$ & $96.8 \pm 7.02$ & $217.0 \pm 8.12$ & $183.4 \pm 7.62 *$ & $145.4 \pm 8.12 * *$ & $111.6 \pm 8.22 * * *$ & $105.8 \pm 7.88^{* * *}$ \\
\hline Hexane extract $200 \mathrm{mg} / \mathrm{kg}$ & $106.2 \pm 8.02$ & $212.6 \pm 7.09$ & $172.6 \pm 6.92 * *$ & $162.4 \pm 6.86^{* *}$ & $120.8 \pm 7.12 * * *$ & $114.4 \pm 7.08 * * *$ \\
\hline Hexane extract $400 \mathrm{mg} / \mathrm{kg}$ & $95.0 \pm 6.12$ & $212.6 \pm 7.32$ & $165.4 \pm 7.16^{* *}$ & $132.8 \pm 6.82 * * *$ & $108.8 \pm 7.09^{* * *}$ & $91.6 \pm 6.12 * * *$ \\
\hline
\end{tabular}

Values are in mean \pm SEM $(\mathrm{n}=6), * \mathrm{P}<0.05, * * \mathrm{P}<0.01, * * * \mathrm{P}<0.00$ Vs Diabetic Control

Table 3 Effect of different extracts of $C$. ignus leaf on lipid profiles in Streptozotocin induced wistar albino rats

\begin{tabular}{|c|c|c|c|c|c|}
\hline \multirow{2}{*}{ Drug Treatment } & \multicolumn{5}{|c|}{ Lipid Profiles (mg/dl) } \\
\hline & Total Cholesterol & Triglycerols & HDL - Cholesterol & LDL - Cholesterol & VLDL - Cholesterol \\
\hline Control & $111.32 \pm 5.87$ & $71.37 \pm 5.91$ & $34.83 \pm 3.28$ & $42.11 \pm 2.63$ & $18.63 \pm 1.08$ \\
\hline Diabetic Control & $142.80 \pm 6.90$ & $113.62 \pm 6.31$ & $21.63 \pm 1.01$ & $76.25 \pm 4.89$ & $31.54 \pm 1.76$ \\
\hline Glibenclamide & $119.01 \pm 7.62^{* * *}$ & $72.55 \pm 4.82^{* * *}$ & $33.57 \pm 1.16^{* * *}$ & $45.16 \pm 2.60 * * *$ & $21.14 \pm 1.70 * *$ \\
\hline Hot Water Extract $200 \mathrm{mg}$ & $123.72 \pm 6.03 *$ & $91.14 \pm 6.24 * *$ & $26.63 \pm 0.87^{*}$ & $58.18 \pm 3.42 * *$ & $23.59 \pm 1.62 *$ \\
\hline Hot Water Extract $400 \mathrm{mg}$ & $117.74 \pm 4.42 * *$ & $72.93 \pm 3.76^{* * *}$ & $32.17 \pm 1.73 * * *$ & $45.05 \pm 2.97 * * *$ & $22.68 \pm 1.71 * *$ \\
\hline Acetone Extract $200 \mathrm{mg}$ & $123.90 \pm 5.20 *$ & $88.42 \pm 3.61 * *$ & $25.63 \pm 1.92 *$ & $61.35 \pm 4.42 *$ & $24.50 \pm 1.62 *$ \\
\hline Acetone Extract $400 \mathrm{mg}$ & $116.22 \pm 4.40 * *$ & $73.50 \pm 3.17 * * *$ & $31.47 \pm 2.46^{* * * *}$ & $43.06 \pm 1.97 * * *$ & $21.67 \pm 1.71 * *$ \\
\hline Hexane Extract $200 \mathrm{mg}$ & $127.15 \pm 5.21^{*}$ & $88.14 \pm 3.24^{* *}$ & $25.82 \pm 1.02^{*}$ & $57.32 \pm 2.42 * *$ & $24.51 \pm 1.62 *$ \\
\hline Hexane Extract $400 \mathrm{mg}$ & $118.62 \pm 3.19^{* *}$ & $75.36 \pm 5.27 * * *$ & $31.61 \pm 1.94 * * *$ & $45.60 \pm 3.97 * * *$ & $20.66 \pm 1.71 * *$ \\
\hline
\end{tabular}

Values are in mean $\pm \operatorname{SEM}(\mathrm{n}=6), * \mathrm{P}<0.05, * * \mathrm{P}<0.01, * * * \mathrm{P}<0.001$ Vs Diabetic Control

found $119.8 \pm 3.16 \mathrm{mg} / \mathrm{dl}$. Among various tested extract, 200 $\mathrm{mg} / \mathrm{kg}$ of hot water extract of C. igneus leaves moderately decreased the blood sugar level $(142.8 \pm 8.02)$ from $4^{\text {th }}$ day onwards and the effect was maintained until the end of the treatment against the reference control $119.8 \pm 3.16 \mathrm{mg} / \mathrm{dl}$. As compared to other extracts, hexane extracts C. igneus at $400 \mathrm{mg} / \mathrm{kg}$ has shown high significant $(\mathrm{P}<0.001)$ decrease in blood sugar levels $(91.6 \pm 6.12)$ form $7^{\text {th }}$ day to $28^{\text {th }}$ day of treatment as that of the reference control $119.8 \pm 3.16 \mathrm{mg} / \mathrm{dl}$.

\subsection{Effect of leaf extracts of C. igneus on Lipid Profile}

The results of analysis of Total cholesterol (TC), Triglycerides (TG), High Density Lipoprotein Cholesterol (HDL-C), Low Density Lipoprotein Cholesterol (LDL-C) and Very Low Density Lipoprotein Cholesterol (VLDL-C) are given in Table 3.

\subsubsection{Total cholesterol}

The animals treated with streptozotocin (STZ) have higher value of total cholesterol as compared to normal control. Glibenclamide (5 $\mathrm{mg} / \mathrm{kg}$ ) treatment significantly $(\mathrm{P}<0.001)$ reduced the level of total cholesterol (119.01 \pm 7.62$)$ which enhanced by STZ treatment $(142.80 \pm 6.90)$. The low dose $(200 \mathrm{mg} / \mathrm{kg})$ of hot water, acetone and hexane extracts of $C$. igneus were observed less significant $(\mathrm{P}<0.05)$ in reducing cholesterol level as compared to diabetic control. High dose $(400 \mathrm{mg} / \mathrm{kg})$ of hot water $(117.74 \pm 4.42)$ and acetone leaf $(116.22 \pm 4.40)$ extract of $C$. igneus was found more significant $(\mathrm{P}<0.01)$ to decrease cholesterol as compared to diabetic control $(142.80 \pm 6.90)$. Similarly high dose $(400 \mathrm{mg} / \mathrm{kg})$ of hexane extracts of C. igneusfound more significant $(\mathrm{P}<0.01)$ to reduce cholesterol level (118.62 \pm 3.19$)$ as compared to diabetic control (142.80 \pm 6.90$)$. 


\subsubsection{Triglycerols}

The animals treated with streptozotocin (STZ) enhanced the triglycerides compared to normal control. Treatment with glibenclamide $(5 \mathrm{mg} / \mathrm{kg})$ significantly $(\mathrm{P}<0.001)$ decreased the level of triglycerides $(113.62 \pm 6.31)$ enhanced by streptozotocin (STZ) $(113.62 \pm 6.31)$. The low dose $(200 \mathrm{mg} / \mathrm{kg})$ of hot water, acetone and hexane extracts of $C$. igneus were find less significant $(\mathrm{P}<0.05)$ to decrease triglycerides. Whereas hot water

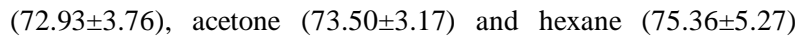
extract at $400 \mathrm{mg} / \mathrm{kg}$ has shown high significance $(\mathrm{P}<0.01)$ reduction in triglycerides level $(75.36 \pm 5.27)$ as compared to diabetic control (113.62 \pm 6.31$)$.

\subsubsection{HDL Cholesterol}

The animals treated with streptozotocin (STZ) have elevated level of HDL cholesterol compared to normal control. Glibenclamide (5 $\mathrm{mg} / \mathrm{kg})$ significantly $(\mathrm{P}<0.001)$ decreased the level of $\mathrm{HDL}$ cholesterol (33.57 \pm 1.16$)$. Low dose $(200 \mathrm{mg} / \mathrm{kg})$ of hot water (26.63 \pm 0.87$)$, acetone $(25.63 \pm 1.92)$ and hexane $(25.82 \pm 1.02)$ extracts of $C$. igneus were found less significant $(\mathrm{P}<0.05)$ to decrease the level of HDL cholesterol as compared to diabetic control (21.63 \pm 1.01$)$. Whereas high dose $(400 \mathrm{mg} / \mathrm{kg})$ of hot water $(32.17 \pm 1.73)$, acetone $(31.47 \pm 2.46)$ and hexane $(31.61 \pm 1.94)$ extract of $C$. igneus were found more significant $(\mathrm{P}<0.01)$ in reducing the level of $\mathrm{HDL}$ cholesterol as compared to diabetic control (21.63 \pm 1.01$)$.

\subsubsection{LDL and VLDL Cholesterol}

Induction of streptozotocin (STZ) in animals increased the LDL cholesterol compared to normal control. Treatment with glibenclamide $(5 \mathrm{mg} / \mathrm{kg})$ significantly $(\mathrm{P}<0.001)$ reduced the LDL cholesterol level (45.16 \pm 2.60$)$ enhanced by streptozoztocin (STZ) (76.26 \pm 4.89$)$. It was observed that low dose $(200 \mathrm{mg} / \mathrm{kg})$ of hot water $(58.18 \pm 3.42)$, acetone $(61.35 \pm 4.42)$ and hexane (57.32 \pm 2.42$)$ extracts of C.igneus were less significant $(\mathrm{P}<0.05)$ in reducing the LDL cholesterol level as compared to diabetic control $(76.26 \pm 4.89)$. The high dose $(400 \mathrm{mg} / \mathrm{kg})$ of hot water extracts of $C$. igneus was found more significant $(\mathrm{P}<0.01)$ to reduce LDL cholesterol level (45.05 \pm 2.97$)$. Similarly high dose $(400 \mathrm{mg} / \mathrm{kg})$ of acetone and hexane extracts of C. igneus more significantly $(\mathrm{P}<0.01)$ reduced the $\mathrm{LDL}$ cholesterol level (43.06 \pm 1.97$),(45.60 \pm 3.97)$ respectively as compared to diabetic control (76.26 \pm 4.89$)$. The results of VLDL cholesterol analysis revealed that there was less significant $(\mathrm{P}<0.05)$ reduction of VLDL cholesterol levels on treatment with hot water, acetone and hexane leaf extracts of $C$. igneus as compared to diabetic control. High dose $(400 \mathrm{mg} / \mathrm{kg})$ of hot water leaf extract $C$. igneus showed more significant $(\mathrm{P}<0.01)$ potential in reduction of VLDL cholesterol $(22.68 \pm 1.71)$ as compared to diabetic control (31.54 \pm 1.76$)$. Similarly high dose of acetone and hexane extracts of C. igneus leaves also showed more significant $(\mathrm{P}<0.01)$ reduction in VLDL cholesterol $(21.67 \pm 1.71), \quad(20.66 \pm 1.71)$ respectively as compared to diabetic control (31.54 \pm 1.76$)$.

\subsubsection{Effect of different leaf extracts on serum blood urea nitrogen (BUN)}

The effects of various leaf extracts of $C$. igneus on serum blood urea nitrogen (BUN) in STZ induced diabetes rats and the results were shown in the Table 4.The blood urea nitrogen was increased in the STZ induced diabetes animals as compared to normal control animals. Hot water and acetone leaf extracts of $C$. igneus at dose of $200 \mathrm{mg} / \mathrm{kg}$ showed less significance $(\mathrm{P}<0.05)$ in bringing down blood urea nitrogen level as compared to diabetic control. Whereas hexane extract at $200 \mathrm{mg} / \mathrm{kg}$ found significant $(\mathrm{P}<0.01)$ in lower down the blood urea nitrogen $(38.17 \pm 2.22)$. At high dose $400 \mathrm{mg} / \mathrm{kg}$ among all the three leaf extracts of $C$. igneus, hexane extract showed high significance $(\mathrm{P}<0.001)$ in reduction of blood urea nitrogen level $(30.52 \pm 1.42)$ as compared to diabetic control $(51.82 \pm 2.67)$. It was observed the effect of hexane extract on blood urea nitrogen was equipotent as that of the reference control Glibenclamide.

Table 4 Effect of various leaf extracts of $C$. igneus on Blood urea nitrogen and Creatinine in Streptozotocin induced wistar albino rats

\begin{tabular}{|c|c|c|}
\hline \multirow{2}{*}{$\begin{array}{c}\text { Drug } \\
\text { Treatment }\end{array}$} & \multicolumn{2}{|c|}{ Kidney Function Test } \\
\hline & $\begin{array}{l}\text { BUN } \\
(\mathrm{mg} / \mathrm{dl})\end{array}$ & $\begin{array}{l}\text { Creatinine } \\
(\mathrm{mg} / \mathrm{dl})\end{array}$ \\
\hline Control & $22.32 \pm 1.72$ & $0.48 \pm 0.06$ \\
\hline Diabetic Control & $51.82 \pm 2.67$ & $0.16 \pm 0.01$ \\
\hline Glibenclamide & $32.56 \pm 1.63^{* * *}$ & $0.37 \pm 0.04 * * *$ \\
\hline Hot Water Extract $200 \mathrm{mg}$ & $48.73 \pm 2.22 *$ & $0.29 \pm 0.01 *$ \\
\hline Hot Water Extract $400 \mathrm{mg}$ & $31.62 \pm 5.86^{* * *}$ & $0.34 \pm 0.01 * * *$ \\
\hline Acetone Extract $200 \mathrm{mg}$ & $45.61 \pm 2.09^{*}$ & $0.24 \pm 0.01 *$ \\
\hline Acetone Extract $400 \mathrm{mg}$ & $32.50 \pm 1.62 * * *$ & $0.35 \pm 0.02 * * *$ \\
\hline Hexane Extract $200 \mathrm{mg}$ & $38.17 \pm 2.22 * *$ & $0.29 \pm 0.01 *$ \\
\hline Hexane Extract $400 \mathrm{mg}$ & $30.52 \pm 1.42 * * *$ & $0.36 \pm 0.01 * * *$ \\
\hline
\end{tabular}

Values are in mean \pm SEM $(\mathrm{n}=6), * \mathrm{P}<0.05, * * \mathrm{P}<0.01, * * * \mathrm{P}<0.001 \mathrm{Vs}$ Diabetic Control

\subsubsection{Effect of different leaf extracts on Serum Creatinine}

Serum creatinine level was enhanced by the STZ administration and it was reversed by the Glibenclamide. Treatment containing $200 \mathrm{mg} / \mathrm{kg}$ dose of $C$. igneus hot water has less significant $(\mathrm{P}<0.05)$ effect on reducing creatinine level $(0.29 \pm 0.01)$ similar effect has been reported for $200 \mathrm{mg} / \mathrm{kg}$ dose of acetone $(0.24 \pm 0.01)$ and hexane $(0.29 \pm 0.01$ extract. Further a significant reduction was reported in serum creatinine level at $400 \mathrm{mg} / \mathrm{kg}$ in 
all the three, hot water $(0.34 \pm 0.01)$, acetone $(0.35 \pm 0.02)$ and hexane $(0.36 \pm 0.01)$ leaf extracts of $C$. igneus as compared to normal control $(0.48 \pm 0.06)$. The effect produced by hot water, acetone and hexane leaf extracts of $C$. igneusat dose of $400 \mathrm{mg} / \mathrm{kg}$ was similar to effect produced by that of Glibenclamide $(0.37 \pm 0.04)$.

\section{Discussion}

The results of the study revealed that all the extracts of $C$. igneus did not have any mortality at $2000 \mathrm{mg} / \mathrm{kg}$ even after 72 hours. Although acetone and hexane extracts showed mile sedation while hexane extract showed muscle relaxant and CNS depressant activity at $2000 \mathrm{mg} / \mathrm{kg}$. Further hot water extract didn't alter the general behaviour of experimental animals. No lethality or toxic reactions found during and after the study period with all the three different extract of $C$. igneus. Substances with 50\%lethal dose of $1000 \mathrm{mg} / \mathrm{kg}$ body weight/oral route are regarded as being safe or of low toxicity as per (Clarke \& Clarke, 1977).

Plant derivatives with hypoglycemic properties have been used in folk medicine and traditional healing systems around the world from ancient times. Despite, the introduction of hypoglycemic agents from natural and synthetic sources, diabetes and its secondary complications continue to be a major medical problem to people (Ravi et al., 2005). Medicinal plants used to treat hypoglycemic and hyperglycemic conditions are of considerable interest to ethno-botanical community as the plants contain valuable medicinal properties in its different parts. Study carried by Palanivel et al. (2013) observed that diabetic rats treated with ethanolic extract of C. igneus $250 \mathrm{mg} / \mathrm{kg}$ decreased blood glucose levels at the end treatment which was carried for 14 days indicating good hypoglycemic activity. Treatment with ethanolic and aqueous extracts of $C$. igneus at a dose of $500 \mathrm{mg} / \mathrm{kg}$ showed significant reduction in increased blood glucose (Kumudhavalli \& Jaykar, 2012).

Present study on hypoglycemic effect of $C$. igneus in streptozotocin induced diabetic rats revealed that experimental animals with blood glucose range of above $200 \mathrm{mg} / \mathrm{dl}$ were considered as diabetic rats after the administration of STZ. Glibenclamide was used as reference control and it significantly reduced the blood sugar levels. $200 \mathrm{mg} / \mathrm{kg}$ dose of hexane extract of $C$. igneus showed significant $(\mathrm{P}<0.001)$ decline in blood sugar level. Among the higher doses of $400 \mathrm{mg} / \mathrm{kg}$ hexane extract of $C$. igneus showed high significant $(\mathrm{P}<0.001)$ reduction in blood sugar level form $7^{\text {th }}$ day to $28^{\text {th }}$ day of treatment.

Reports of clinical trials have demonstrated that the increase in plasma low density lipoprotein cholesterol (LDL-C) levels is implicated in the early development and progression of atherosclerosis. West et al. (1983) revealed that in diabetes triglycerides are also a risk and high density lipoprotein cholesterol (HDL-C) is an anti-atherogenic fraction. In normal condition it is well known that lipoprotein lipase enzyme is activated by insulin and hydrolyzes the triglycerides. The reports of previous studies on evaluation of anti-diabetic effect of ethanolic and aqueous extracts of C.ignues in streptozotocin induced diabetes. The treatment with ethanolic and aqueous extracts of C.ignues at a dose of $500 \mathrm{mg} / \mathrm{kg}$ for the period of 15 days showed significant reduction in cholesterol, triglycerides, LDL and elevated the decreased HDL level as that of standard (Kumudhavalli \& Jaykar, 2012).

The effect of different leaf extracts of $C$. igneus on blood serum sample were subjected to lipid analysis and biochemical parameters like total cholesterol (TC), triglycerides (TG), high density lipoprotein cholesterol (HDL-C), low density lipoprotein cholesterol (LDL-C) and very low density lipoprotein cholesterol (VLDL-C) in the present study. The animals treated with streptozotocin (STZ) have higher value of total cholesterol as compared to normal control. Glibenclamide $(5 \mathrm{mg} / \mathrm{kg}$ ) treatment significantly $(\mathrm{P}<0.001)$ reduced the level of total cholesterol which enhanced by STZ treatment. The low dose $(200 \mathrm{mg} / \mathrm{kg})$ of hot water, acetone and hexane extracts of $C$. igneus were observed less significant $(\mathrm{P}<0.05)$ in reducing cholesterol level as compared to diabetic control. The high dose $(400 \mathrm{mg} / \mathrm{kg})$ of hot water leaf extract and acetone extract of $C$. igneus was found more significant $(\mathrm{P}<0.01)$ to decrease cholesterol respectively as compared to diabetic control. Similarly high dose $(400 \mathrm{mg} / \mathrm{kg})$ of hexane extracts of $C$. igneus found more significant $(\mathrm{P}<0.01)$ to reduce cholesterol level as compared to diabetic control.

The animals treated with streptozotocin (STZ) enhanced the triglycerides compared to normal control. Treatment with glibenclamide $(5 \mathrm{mg} / \mathrm{kg})$ significantly $(\mathrm{P}<0.001)$ decreased the triglycerides enhanced by streptozotocin (STZ). The low dose $(200 \mathrm{mg} / \mathrm{kg}$ ) of hot water, acetone and hexane extracts of $C$. igneus were find less significant $(\mathrm{P}<0.05)$ to decrease triglycerides. Whereas higher dose $(400 \mathrm{mg} / \mathrm{kg})$ of hot water extract found significant $(\mathrm{P}<0.01)$ in reducing triglyceride level. Similarly high dose $(400 \mathrm{mg} / \mathrm{kg})$ of acetone extract was found more significant $(\mathrm{P}<0.01)$ to decrease triglycerides. The high dose (400 mg/kg) of hexane extract of C. igneus also found more significantly $(\mathrm{P}<0.01)$ in reducing triglycerides level as compared to diabetic control.

The animals treated with streptozotocin (STZ) have elevated level of HDL cholesterol compared to normal control. Glibenclamide (5 $\mathrm{mg} / \mathrm{kg})$ significantly $(\mathrm{P}<0.001)$ decreased the level of $\mathrm{HDL}$ cholesterol. Lower dose $(200 \mathrm{mg} / \mathrm{kg})$ extracts of C.igneus were found less significant $(\mathrm{P}<0.05)$ to decrease the level of HDL cholesterol. Whereas higher dose $(400 \mathrm{mg} / \mathrm{kg})$ extracts were found 
more significant in reducing HDL cholesterol level as compared to diabetic control $(\mathrm{P}<0.01)$.

Induction of streptozotocin (STZ) in animals increased the LDL cholesterol and VLDL cholesterol compared to normal control. Treatment with glibenclamide $(5 \mathrm{mg} / \mathrm{kg})$ significantly $(\mathrm{P}<0.001)$ reduced the LDL cholesterol level enhanced by streptozoztocin (STZ). It was observed that all three extracts of C. igneus (200 $\mathrm{mg} / \mathrm{kg}$ ) were less significant $(\mathrm{P}<0.05)$ in reducing the $\mathrm{LDL}$ cholesterol and VLDL cholesterol levels. However high dose (400 $\mathrm{mg} / \mathrm{kg})$ of $C$. igneus extracts was found more significant $(\mathrm{P}<0.01)$ to reduce LDL cholesterol and VLDL cholesterol level.

Pervious study by Palanivel et al. (2013) reported that $C$. igneus ethanolic extract (Whole plant) $250 \mathrm{mg} / \mathrm{kg}$ also showed statistically significant decrease $(\mathrm{p}<0.01)$ in blood urea nitrogen and creatinine levels as compared to diabetic control. The reduction in BUN in animals receiving various plant extracts interpreted as mechanism responsible for reabsorption of urea in nephrons. Creatinine, on other hand is organic base formed of degradation outcome of creatinine phosphate produced in muscle protein metabolism Mayes, (1988).

In the present study the effects of various extracts of $C$. igneus leaves on serum blood urea nitrogen (BUN) and creatinine in STZ induced diabetes in rats showed that the blood urea nitrogen and serum creatinine was increased in the STZ induced diabetes animals as compared to normal control animals. Treatment with C. igneus hexane extracts have highly significance $(\mathrm{P}<0.001)$ effect in reduction of blood urea nitrogen level at both concentrations and its effect on blood urea nitrogen was equipotent as glibenclamide. Similarly the high dose $(400 \mathrm{mg} / \mathrm{kg})$ of all the extracts of $C$. igneus has shown a significant reduction in serum creatinine level $(\mathrm{P}<0.001)$.

\section{Conclusion}

Acute toxicity studies of $C$. igneus extracts revealed notoxic reactions and did not have any mortality at $2000 \mathrm{mg} / \mathrm{kg}$ even after 72 hours. Hexane extract of $C$. igneus shown high significant hypoglycaemic activity in streptozotocin induced diabetic rats and at $400 \mathrm{mg} / \mathrm{kg}$ extracts of $C$. igneus has shown high significance in reduction of serum lipid profile. The effect of hexane extract at $400 \mathrm{mg} / \mathrm{kg}$ on blood urea nitrogen and serum creatinine was similar to the effect produced by glibenclamide. The present study explored that $C$. igneus has potential to reduce the blood glucose level and other factors associated with diabetes. Hence $C$. igneus can act as natural, safe and cost-effective for the treatment of diabetes.

\section{Conflict of interest}

The corresponding author declares that there is no conflict of interest.

\section{Funding sources}

This research did not receive any specific grants from funding agencies in public, commercial or not-for- profit sectors.

\section{Acknowledgment}

I express my sincere and special thanks to Dr. S. Sengottuvelu, Head and Mr. S. HajaSherief, Assistant Professor, Department of Pharmacology, Nandha College of Pharmacy, Erode Tamilnadu India for permitting me to work in his laboratory to carry out the animal model study

\section{References}

Abou I, Ghanema (2013) Biochemical and hematological evaluation of Costus speciosus as a dietary supplement to Egyptian buffaloes. African Journal of Pharmacy and Pharmacology 7: 2774-2779.

Aslam M, Orhan, DD, Orhan N, Sezik E, Yesilada (2007) In vivo anti diabetic and antioxidant potential of Helichrysum plicatum ssp. Plicatum capitulums in streptozotoc in induced diabetic rats. Journal of Ethnopharmacology 109: 54-59.

Awanish P, Poonam T, Rishabh P, Rashmi S, Shambaditya G (2011) Alternative therapies useful in the management of diabetes: A systematic review. Journal of Pharmacy and Bioallied Sciences 3: 504-512.

Bimal K, Rai B, Nisha A (2011) Synthesis, characterization and antimicrobial screening of Cobalt (II), Nickel(II) and Copper(II) complexes with schiff base derived from 2-Phenyl Quinoxaline Thiosemicarbazone. Oriental Journal of Chemistry 27: 1173-1178.

Clarke ECG, Clarke ML (1977) Veterinary toxicology. Cassed and Collier, Lodon, Pp.268-277.

Collier E, Watkinson A, Cleland C, Roth J (1987) Partial purification and characterization of an insulin-like material from spinach and Lemnagibba G3. Journal of Biological Chemistry 262: 6238-6241.

Ecobichon DJ (1997) The Basis of Toxicology Testing. CRC Press, New York, Pp. 43-86.

Eddouks M, Jouad H, Maghrani M, Lemhadri A, Burcelin R (2003) Inhibition of endogenous glucose production accounts for hypoglycemic effect of Spergularia purpurea in streptozotocin mice.Phytomedicine.International Journal of Phytothereupetics and Phytopharmacology 10: 594-599.

Friedewald WT, Levy RI, Fredrickson DS (1972) Estimation of the concentration of low-density lipoprotein cholesterol in plasma, without use of the preparative ultracentrifuge. Clinical Chemistry 18: 499-502. 
Gray A, Flatt P (1999) Insulin-releasing and insulin-like activity of the traditional anti-diabetic plant Coriandrumsativum (coriander). British Journal of Nutrition 81:203-208.

Jafari E, Andalib S, AbedA, Rafieian-Kopaei M Vaseghi G, Eshraghi A (2011) Neurological, antimicrobial, antioxidant, chemotherapeutic, and antidiabetic properties of Salvia Reuterana: A mini review. Avicenna Journal Of Phytomedicine 5 : 10-16.

Khan A, Bryden N, Polasky M, Anderson RA (1990) Insulinpotentiating factor and chromium content of selected spices. Biological Trace Element Research 24:183-188.

Kumudhavalli, Jaykar B (2012) Evaluation of Antidiabetic activity of Costus igneus (L) leaves on STZ induced diabetic rats. Der Pharmacia Sinica 3: 1- 4.

Lopes-Virella MF Stone P, Ellis S, Colwell JA (1977) Cholesterol determination in high density lipoproteins separated by three different methods. Clinical Chemistry 23: 882-884.

Maritim A, Sander R, Watkinsjbiii (2003) Diabetes, oxidative stress, and antioxidants: a review. Journal of Biochemical and Molecular Toxicology 17: 24-38.

Mayes PA (1988) Bioenergetics. In: Murray RK, Granner DK, Mayes PA, Rodwell VW (Eds.), Harpers Biochemistry. Appleton Lange, California 97-99.

Mclarty J (1997) Antioxidants and cancer, the epidemiologic evidence. In: Garewal HS (Ed.), Antioxidants and Disease Prevention. CRC Press, New York. 45-66

Mehta J, Rasouli N, Sinhaak, Molavi B (2006) Oxidative stress in diabetes: A mechanistic overview of its effects on atherogenesis and myocardial dysfunction. International Journal of Biochemistry and Cell Biology 38: 794-803.

Mukherjee P, Maiti K, Mukherjee K, Houghton PJ (2006) Leads from Indian medicinal plants with hypoglycemic potentials. Journal of Ethnopharmacology 106: 1-28.

Musabayane CT, Bwititi PT, Ojewole, JAO (2006) Effects of orally-administered herbal extracts on food consumption and blood glucose levels in normal and streptozotocin-treated diabetic rats. Methods and Findings in Experimental and Clinical Pharmacology $28: 223-228$.

Natelson S, Scott MS, Beffa C (1951) A rapid method for the estimation of urea in biological fluids. Amrican Journal of Clinical Pathology21: 275-81.

Palanivel V, Mohammed Shaf I, Senthil Kumar KL (2013)Antidiabetic and Hypolipidemic activities of Momordictuberosaunripe fruit extract on diabetic induced rats. International Journal of Advanced Pharmaceutical Genuine Research1: 33-40.

Ravi K, Rajasekaran S, Subramanian S (2005) Antihyperlipidemic effect of Eugenia jambolana seed kernel on streptozotocin-induced diabetes in rats. Food Chemistry and Toxicology 43: 1433-1439.
Roeschlau P, Bernt E, Gruber WA (1974) Enzymatic determination of total cholesterol in serum. Clinical Biochemistry 12: $226-228$.

Saraswat M, Suryanarayana P, Reddy P, Patil M, Balakrishna N, Reddy G ( 2010) Antiglycating potential of Zingiber officinalisand delay of diabetic cataract in rats. Molecular Vision 16:1525- 1537 .

Shanmugasundaram E, Gopith K, Radha S, Rajendram VM (1990) Possible regeneration of the islets of Langerhans in streptozotocin-diabetic rats given Gymnema sylvestre leaf extracts. Journal of Ethnopharmcology 30: 265-269.

Slot C (1965) Plasma creatinine determination: a new and specific jaffe reaction method. Scandinavian Journal of Clinical Investigation 17: 381 .

Sun Y, Chu Y, Wu XZ (2002) Antioxidant and antiproliferative activities of common fruits. Journal of Agriculture Food Chemistry 50: 7449-7454.

Tende J, Ezekiel I, Dikko A, Goji AT (2011) Effect of ethanolic leave extract of Moringa oleifera on blood glucose levels of alloxan induced diabetes and monoglycemic wistar rat. British Journal of Pharmacology and Toxicology $2: 1-4$.

Tietz, NW (1990) Clinical guide to laboratory tests.2nd ed. W.B. Saunders Company, Philadelphia.

Trivedi N, Mazumder B, Bhatt J, Hemavathi KG (2004) Effect of Shilajit on blood glucose and lipid profile in alloxan-induced diabetic rats. Indian Journal of Pharmacology 36: 373-376.

Ugwuja E, Nwibo A, Ugwu N, Aloke C (2010) Effects of aqueous extract of spices mixture containing curry, garlic and ginger on plasma glucose and lipids in alloxan-induced diabetic rats. Pakistan Journal of Nutrition9:1131-1135.

Van den-BergheG,Wilmer A, Hermans G, Meersseman W, Wouters P, Milants I, VanWijngaerden E, Bobbaers H, Bouillon R (2006) Intensive insulin therapy in the medical ICU. England Journal of Medicine 354:449-461.

West KM, Ahuja, Bennett PH(1983) The role of circulating glucose and triglyceride concentrations and their interactions with other 'risk factors' as determinants of arterial disease in nine diabetic population samples from the WHO multinational study. Diabetes Care 6:361-369.

Yadav P, Saini S, Kalia A, Dangi AS (2008) Hypoglycemic and hypolipidemic activity of ethanolic extract of Salvadora oleoides in normal and alloxan-induced diabetic rats. Indian Journal of Pharmacology 40: 23-27.

Yang C, Landau J, Huang MT (2001) Inhibition of carcinogenesis by dietary polyphenolic compounds. Annual Review of Nutrition 21: 381-406.

Young I, Wood JV (2001) Antioxidants in health and disease. Journal of Clinical Pathology 54: 176-186. 